\title{
Speaker's stance and subjectivity in the epistemic modal and evidential use of the Spanish imperfecto in journalistic texts
}

\author{
Verónica Böhm \\ Universität Potsdam
}

\begin{abstract}
This study contributes to the analysis of the epistemic modal and evidential use of the Spanish imperfecto with regard to the speaker's stance and subjectively (rather than grammatically) motivated decision to use the Spanish imperfecto as an evidential strategy in journalistic texts: The speaker uses the Spanish imperfecto to express or tell a state of affairs from his perspective as a 'narrator', implying that he is not the author of such information and referring to third sources without mentioning it. The corpus data were obtained from the Corpus de la Real Academia Española (CREA) from the section 'written journalistic texts' of the standard Iberian Spanish to guarantee the authenticity of examples and avoid any case of misunderstanding it as a variety of Spanish.
\end{abstract}

Keywords: Spanish imperfecto, aspectuality, epistemic modality, evidentiality, journalistic texts, corpus analysis, functional linguistics

\section{Introduction}

It has been shown that the secondary values ${ }^{1}$ of the Spanish imperfecto are linked to epistemic modality and evidentiality. 'Epistemic modality' should be understood as the speaker's stance towards his knowledge or belief regarding a state of affairs (for example, I think, I know, etc.) while 'evidentiality' is related to the codification of the source of information expressed in an utterance (for example, they said that [...], according to sources, etc.). In terms of evidentiality, one can distin-

1. Some authors (cf. Fernández Ramírez, 1986; Bertinetto, 1986; Reyes, 1990a; Gutiérrez Aráus, 1995a; Leonetti \& Escandell-Vidal, 2003; García Fernández, 2004 and Dessì, 2010) relate the secondary values of the Spanish imperfecto with its modalized and evidential uses, however with much attention paid to oral discourses. 
guish between direct evidentiality and indirect evidentiality. When the speaker has direct evidence (or knowledge) for the state of affairs, one speaks about 'direct evidentiality' (for example, I saw him buying). On the contrary, 'indirect evidentiality' is associated with the speaker's indirect evidence (or knowledge) for the state of affairs, i.e. the speaker obtained the information by hearsay or by inference, as in Peter said that Martha was not coming, apparently Martha will not come (I was told that [...]).

The Spanish imperfecto is used in some contexts to mark the speaker's belief, supposition or lack of knowledge towards what he says (epistemic modality) and to refer to an external source of information (indirect evidentiality):

(1) El presidente del club aragonés, José Luis Rubio, reconocía ayer haber mantenido contactos con otros entrenadores [...].

('The president of the Aragonese club, José Luis Rubio, admitted.IMP' yesterday to have kept contacts with other coaches [...]', CREA, El País, 01/06/1984).

In the previous utterance, the speaker's decision to use the imperfective verb form reconocía instead of the perfective one reconoció - which would be 'normatively' correct because the utterance (1) refers to a punctual situation ${ }^{3}$ - is subjectively and not grammatically motivated. The Spanish imperfecto reconocía in (1) - used instead of the pretérito perfecto simple (perfective verb form) reconoció - does not express its 'typical' or primary (aspectual and temporal) values, i.e. an action in process or simultaneity in the past, as in Ana miraba televisión cuando llegó su mama ('Ana was watching.IMP TV when her mother came'). Its use is rather related to the speaker's epistemic stance towards his utterance to mark indirect evidentiality, indicating implicitly that he is not the author of such information. 'Epistemic stance' refers to the speaker's knowledge of a situation or a state of affairs, i.e., if he has or not the knowledge of what he is saying. In this respect, Reyes (1996,p.12) emphasizes the "quotative value of the Spanish imperfecto" (cf. also Leonetti \& Escandell-Vidal, 2003,pp.135-154; Wachtmeister, 2005) and explains that the speaker uses the Spanish imperfecto to refer to utterances said by others: The speaker indicates that the information was obtained by an external source and shows his lack of responsibility for the content of it (cf. also Manual of RAE 2010,p.445), as in Mañana daba una conferencia María ('María would hold.IMP a conference tomorrow', Reyes, 1996, p.12). García Fernández

2. Abbreviation for the Spanish imperfective form, the imperfecto.

3. The Nueva Gramática (NGLE, 2009, p. 1763) points out that the pretérito perfecto simple is compatible with telic verbs like estallar ('to explode') and morir ('to die') because they have an inherent feature of temporal boundedness. Therefore, the use of the perfective form, as in example (1), is grammatically required and more normal than with the imperfecto. 
(2004,p.90) discusses the "labelled uses" of the Spanish imperfecto in which the common denominator is that of modalization, while Haßler (2012,p.133) classifies the Spanish imperfecto as "a means of coding covert modality" (cf. also Böhm, 2016,pp.299-358). There are also some studies (García Fernández, 2004; Reyes, $1990 b)$ which refer to the narrative use of the Spanish imperfecto when it is used instead of the perfective form, i.e., pretérito perfecto simple, with specific dates or temporally limited adverbs:

(2) Hoy se anunciaba oficialmente en su web, que el disco, aún sin título está en marcha y que estará a la venta el próximo año.

('Today, it was.IMP officially announced on his website that the CD without title is still under way and it will be on sale next year', CREA, El País 13/03/ 2012).

(3) Hace unas horas llegaba la dramática noticia de diez muertos más, ahogados en el Estrecho al hundirse una patera [...].

('A few hours ago the dramatic news of ten more men, who drowned to death in the Straits from a patera sinking came.IMP [...]', CREA, El Diario Vasco, o7/ 02/2001).

Although the previous utterances (2-3) point to the narrative function of the Spanish imperfecto because it is used instead of the pretérito perfecto simple with perfective meaning, the speaker's stance in respect to his knowledge of the states of affairs and how he presents the situation described in the utterances $(2-3)$ should not be ignored. As Aikhenvald (2004, p.310) already mentioned regarding some languages like Pastaza Quechua, it is the speaker's choice how he tells the story or transmits the information. Taking into consideration the indirect evidential function of the Spanish imperfecto, one could say that the speaker refers implicitly to an external source of information which he probably does not want to mention because he considers it unimportant or lacks necessary first-hand information. Thus, the narrative function of the Spanish imperfecto appears to be associated with its evidential function based on the speaker's choice to highlight that he was not eyewitness of the state of affairs.

This study attempts to demonstrate that the speaker's decision to use the imperfective form instead of the perfective one is not only associated with the pragmatic function of the Spanish imperfecto in journalistic texts but also with the speaker's subjective choice to use the Spanish imperfecto as an evidential strategy "to testify [...] [the speaker's] ignorance of a phenomenon" (Aikhenvald, 2004, p.320). 


\section{Starting point for the epistemic modal and evidential use of the Spanish imperfecto}

\subsection{Aspectual indeterminancy}

The aspectual indeterminancy of the Spanish imperfecto builds a 'metonymic bridge' to modality (Dessì, 2010,pp.58-61; Böhm, 2016,p.23). 'Aspectual indeterminancy' is related to the imperfective aspectuality of the Spanish imperfecto. It means that there are no internal temporal boundaries of the beginning or end of a state of affairs expressed by the imperfecto, or at least these are not marked or expressed by the imperfecto. Since the imperfective aspectuality of the Spanish imperfecto presents the state of affairs as non-concluded, undetermined and backgrounded with the possibility to be continued up to the present, the content of the state of affairs cannot be validated, which leads to modality. This can be explained with the use of the imperfecto de conato ('imperfect of attempt'). In the following example, the action of salir ('to go out') was interrupted by the ringing of the telephone:

(4) Ana salía cuando sonó el teléfono.

('Ana was about to go out when the phone rang').

(Gutiérrez Aráus, 1995a, p.51)

The action of 'going out' is open and undetermined with respect to its completion or fulfilment either because the speaker does not want to reveal it or because he does not have the knowledge of that situation, i.e. he does not have direct evidence of it. On the contrary, the perfective aspectuality expressed by the pretérito perfecto simple shows the action as completed and concluded:

(5) Ana salió cuando sonó el teléfono.

('Ana went out when the phone rang').

According to Bazzanella (1990,p.455) the aspectual indeterminacy of the imperfect allows a transfer from the real world to a world created by the speaker. In this way, the Spanish imperfecto can be used with modal values as 'polite', 'oneiric' (dream) and 'ludic' imperfect, etc.

In terms of subjectivity, the reader apparently takes advantage of this aspectual indeterminacy: an open and undetermined situation with respect to its validation opens the possibility for marking the speaker's stance towards his knowledge of the state of affairs which is related to the source of information. If we contextualized the example (4), one could have these possibilities to continue the story: 
(4a) Ana salía cuando sonó el teléfono, pero no sé si llegó a salir. ('Ana was about to go out when the phone rang, but I am not sure if she went $\underline{\text { out }})$.

(4b) Ana salía cuando sonó el teléfono, y creo que lo dejó sonar y salió. ('Ana was about to go out when the phone rang, and I think she let it ring and she went out').

The relationship between the aspectual indeterminancy and epistemic modality relies on the presentation of a state of affairs with open validity. The speaker does not express anything regarding the truth-value of it. For example, the epistemic modal meaning contained in utterance (6) can also be expressed with the Spanish imperfecto (7):

(6) Creo que Ana está en casa.

(Volkmann, 2005, p.60)

('I think (that) Ana is at home').

(7) Tu novio venía a verte mañana, ¿verdad? (Gutiérrez Aráus, 1995a,p.52) ('[They said, I think] Your bridegroom would come.IMP to see you tomorrow, wouldn't he?').

The following figure illustrates the 'metonymic bridge' from the imperfective aspectuality to modality and the modal epistemic value of the Spanish imperfecto: ${ }^{4}$

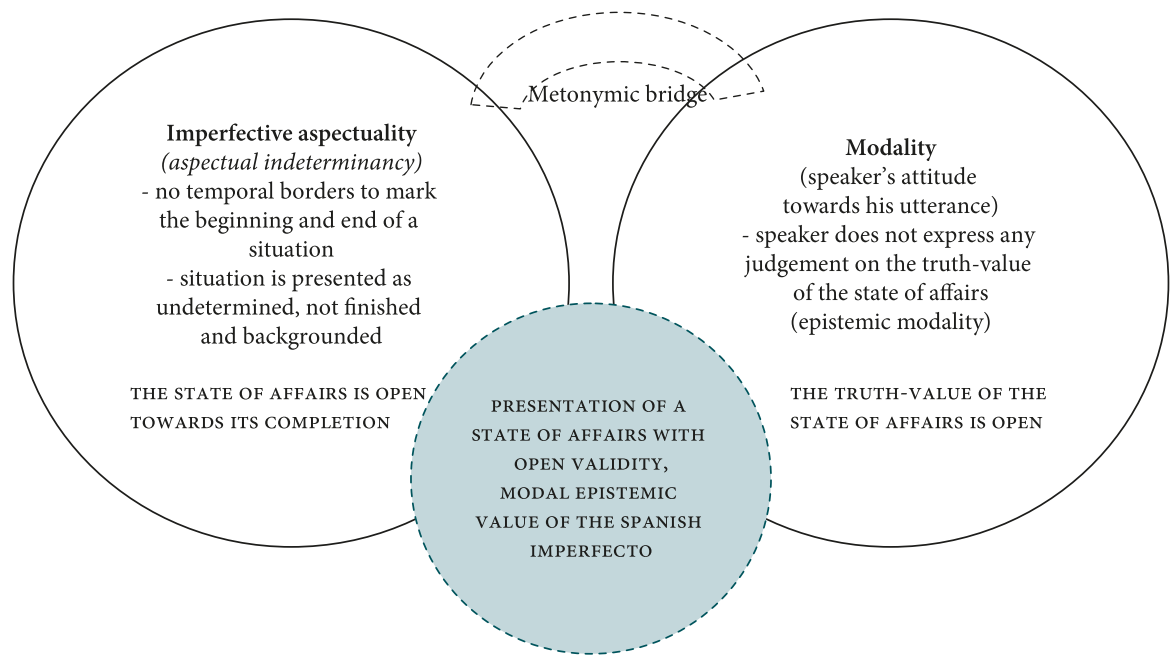

Figure 1. 'Metonymic bridge': From the imperfective aspectuality to the epistemic modal use of the Spanish imperfecto (Böhm, 2016,p.321)

4. The figure presented by Böhm (2016,p.321) has been slightly adapted for our purposes and translated from Spanish to English. 


\subsection{Past tenses developed into evidentials}

Referring to the 'evidential extensions of non-evidential categories', Aikhenvald (2004,p.104) points out that the use of past tenses, among other categories and forms, "acquire secondary meanings [...] related with information source [...] [for they] are called evidentiality strategies. They are distinct from evidentials proper, whose primary - and not infrequently exclusive - meaning is information source". That is the case of the pluperfect (pretérito pluscuamperfecto) in the Spanish of La $\mathrm{Paz}$ (Bolivia) used to indicate 'indirect knowledge' (Aikhenvald, 2004, p.114). Let's see Aikhenvald's examples to this respect:

(8) Hoy día había llegado su mamá de él.

Today had arrived his mother of he.

('Today his mother arrived (but I didn't see her arrive)').

In contrast, the "preterite [pretérito perfecto simple] tends to indicate 'direct knowledge', something the speaker has seen" (Aikhenvald, 2004, p. 114):

(9) Hoy día llegó su mamá de él.

Today arrive.PRET his mother of he.

('Today his mother arrived (and I saw her arrive)').

Even though the pluperfect is a compound past tense and "a past with respect to past" (Laprade, 1981, p. 223), it is, in some cases and depending on the kind of lexical verb, equivalent to the Spanish imperfecto, for it can be used instead of the pluperfect (Aikhenvald, 2004,p.114). In this respect, Bertinetto (1986,p.367) speaks about the neutralization of the Italian imperfetto (10) with the pluperfect piuccheperfetto (11), as Bertinetto's (1986,p.367) examples show:

(10) L'esperienza passata gli insegnava che l'impulsività è controproducente.

('Past experience taught.IMP her that impulsiveness is counterproductive').

(11) L'esperienza passata gli aveva insegnato che l'impulsività è controproducente. ('Past experience had taught.PLUPERF' her that impulsiveness is counterproductive').

The same occurs in Spanish, as we could easily replace the pluperfect of the example (8) by the Spanish imperfecto (example 12) and the sense will not change. However, a little more emphasis on the speaker's uncertainty is made:

5. Abbreviation for the Spanish perfective form, the pretérito perfecto simple.

6. Abbreviation for the Spanish pretérito pluscuamperfecto. 
(12) Hoy día llegaba su mamá de él.

Today arrived.IMP his mother of he.

('Today his mother arrived [but I am not sure]').

The following sentences also show that the pluperfect había estado ('had been') in example (13) and había existido ('had existed') in example (14) can be replaced by the Spanish imperfecto:

(13) Poco antes -las seis de la tarde del pasado miércoles- había estado [estaba] en un bar que dista unos veinte metros del lugar del crimen.

('[...] Shortly before-at six o'clock in the afternoon last Wednesday-[he] had been.PLUPERF [was.IMP] in a bar which is $20 \mathrm{~m}$ far from the crime', CREA, La Voz de Galicia, 1991).

(14) Aseguró además que al PSOE se le anuló una factura de 19 millones porque había existido [existía] un error y trató de desvincular este hecho del pago por Filesa [...].

(' $[\mathrm{He}]$ also said that the PSOE canceled an invoice of 19 million because it had been.PLUPERF [was.IMP] an error, and he tried to dissociate this fact of payment by Filesa [...]', CREA, La Vanguardia, 03/12/1994).

It seems then to be no problem to apply such particularity of the pluperfect to the Spanish imperfecto, which in some special contexts can be used to indicate something the speaker has not seen or the speaker's knowledge about a situation was acquired via a third person. This hypothesis can be confirmed by Aikhenvald's (2004, p. 266) claim - based on the results from her analysis made on data collected from languages which have evidential systems like Tarina, Tucano, Quechua, etc. - that "different evidentials may distinguish different aspects". Following Watkins (1984,pp.173-176), Aikhenvald (2004, p. 266) refers to Kiowa language which "distinguishes an unmarked and an imperfective reported evidential form. The imperfective form is used to report continuous, reported, or habitual event known to the speaker through someone else". Let us observe Aikhenvald's (2004, p.266) example:

(15) dóttè· gyát-kóm-hêl déòp

doctor $\mathrm{x} /$ agent:2sG/patient:PL/object-indicate-REPORTED at+times èm-cą̂.n-ì' t’ó'-dè.

2SG-arrive-IMP/FUT-IMPF.REPORTED.

('You are to be coming at times the doctor indicated to you (I am told)').

7. For more uses of habia with evidential-reportative functions in the Spanish variety resulting from the Quechua-Spanish language contact, cf. Böhm and Hennemann (in press). 
Here, "the speaker is reminding the addressee of a doctor's instructions which were received not directly from the doctor but through the addressee. The imperfective reported attaches to the imperfective future. That is, the aspectual values of the evidential and of the verb must match" (Aikhenvald, 2004, p.266). Although the Spanish tense and aspectual system is built and functions differently from other languages which have tense, aspect and evidentiality as independent systems, the grammatical aspectual opposition perfective/imperfective is expressed by the past tense forms pretérito perfecto simple and pretérito imperfecto respectively:

(16) Benjamín Ramos Vega, de 32 años, trabajaba de administrativo en una empresa de géneros de punto.

('Benjamín Ramos Vega, 32 years old, worked.IMP/used to work as an administrator in a textile industry', CREA, La Vanguardia, 04/05/1994).

(17) Durante algún tiempo trabajó de camionero [...].

('During some time he worked.PPS as a trucker, [...]', CREA, El País, 09/o7/ 1997).

In sentence (16) the Spanish imperfecto shows its imperfective aspectual character expressing a continuous, habitual and repeated action while the pretérito perfecto simple in (17) expresses the development of the action as whole during a specified amount of time. The Spanish imperfecto seems to fulfil all requirements to behave like a reportative evidential marker. Following Giacalone and Topadze (2007,pp.7-8), Böhm and Hennemann (2014, p. 1ff.) indicate that not only the Spanish imperfecto but the conditional developed to evidentials with reportative meanings: "In some languages, evidential meanings 'have developed as secondary meanings out of tenses and moods of the verbal system'. Such evidential, more precisely, reportive meanings have developed out of the Spanish condicional and the imperfecto [...]".

For other Romance languages like Italian and French, whenever the imperfecto is used instead of the preterite (the perfective form), especially in journalistic texts, one speaks of the 'narrative imperfect', for example, in Italian l'imperfetto narrativo (cf. Bertinetto, 1986) and French l'imparfait narratif (Bres, 2005): ${ }^{8} \mathrm{~A}$ special focus is given to the use of the imperfecto with perfective meaning, taking over the main role of a preterite, by which it expresses a concluded and punctual situation which took place in the past, as examples (18) and (19) show:

8. For more details on the narrative imperfect in Romance languages, cf. Böhm (2016,pp.359-472). 
(18) Le 29 mars 1982, une bombe explosait dans un train Paris-Toulouse. Le jour où débutait le procès de Kopp et Breguet, le 22 avril, une voiture piégée explosait devant le siège du magazine $\mathrm{Al}$ Watan $\mathrm{Al}$ Arabi, rue Marbeuf à Paris. ('On 29th of March 1982 a bomb exploded.IMP in a train in Paris-Tolouse. The day when the trial of Kopp and Breguet began.IMP, on April 22nd, a car bomb exploded.IMP in front of the siege of the magazine Al Watan Al Arabi, Marbeuf Avenue in Paris', Cyberpresse.ca, 12/11/2012, International, Europe).

(19) Il 4 ottobre 1982 Glenn Gould moriva per un ictus a 50 anni appena compiuti. ('In October 1982 Glenn Gould died.IMP because of a stroke just after turning 50 years old', La Stampa.it, 01/12/2012, Spettacoli).

The connection to the speaker's stance towards the source of information is not made. However, Aikhenvald (2004, p.316) pays particular attention to the speaker's perspective when using evidentials in a non-standard way, especially "when an evidential is used in an unexpected way, [...] [to achieve] a stylistic effect, backgrounding or foregrounding the speaker's participation or the information itself". Taking into consideration that the Spanish imperfecto behaves in certain contexts as a reportative evidential with narrative function, it can be assumed that its use is related to the narrator's stance to tell the story or reproduce the information with distance, not being the original author of such information or story. Following Aikhenvald (2004,p.319), in languages like Pastaza Quechua the "choice of an evidential specification in a narrative often depends on the perspective of the speaker. The choice between the reported -shi and the direct -mi may have to do with speaker's point of view [...]. The use of reported does not imply any doubt of the statement - it simply states that the speaker is not the author".

\section{Methodology}

The qualitative data has been extracted from the Corpus de la Real Academia Española (CREA), from the written journalistic texts (sections 'economics', 'politics', 'sports' and 'actuality') of standard Iberian Spanish. For the present study, the journalistic discourse (in written texts) was chosen because it is characterized as producing information or news of public nature and transmitting an objective and brief report (cf. Cappon, 2005,p.11). Thus, fictional texts, in which the pretérito imperfecto - due to its imperfective character - can express unreality or imagination (for example, Érase una vez una princesa ('Once upon the time there was.IMP a princess') are excluded. In the same way, examples in which the Spanish imperfecto expresses its primary aspectual and temporal values (simultaneity in the past, a continuous, ongoing or habitual action, etc.) as well as when it is used with elements that mark explicitly the source of information, for example, 
según fuentes ('according to third sources'), ${ }^{9}$ will be not considered for the analysis. In the selected and analyzed examples, the Spanish imperfecto appears not in subordinated but in main syntactic position and acquires epistemic modal and evidential meaning, for example:

(20) Justamente ayer terminaba el plazo de alegaciones [...].

('Just yesterday the period for presenting objections [...] finished.IMP', CREA, La Vanguardia, 01/06/1994).

In the present study, non-durative verbs like moría ('died.IMP'), estallaba ('exploted.IMP'), pagaba ('paid.IMP') and ascendía ('rose.IMP') - which are semantically perfective in nature, and thus in normative use would require the perfective form (cf. NGLE, 2009, p.1763) - will be analyzed. Durative verbs (of saying) like expresaba ('expressed.IMP') and decía ('said.IMP') will also be considered for the analysis to observe the speaker's subjectivity when choosing the imperfective form instead of the perfective one expresó ('expressed.IMP') and dijo ('said.IMP') respectively to show his/her dissociation from the state of affairs. Furthermore, it will be demonstrated that the epistemic and evidential use of the Spanish imperfecto in journalistic texts is associated with the speaker's stance to present or transmit the state of affairs from his/her perspective as narrator. The speaker indicates implicitly that (s)he is not the original author of the state of affairs and refers to an external source of information without mentioning it. Also, his/her "commitment to the truth of a proposition" (Bybee \& Fleischman, 1995, p. 6 and Nuyts, 2001) will be taken into consideration, for which the state of affairs expressed by the Spanish imperfecto will have a lower degree of assertiveness.

\section{Analysis and results of the epistemic modal and evidential use of the} Spanish imperfecto under the speaker's subjective perspective to mark implicitly an external source of information

4.1 The Spanish imperfecto with the verbs morir ('to die'), estallar ('to explode'), ascender ('to rise') and pagar ('to pay')

The verbs morir ('to die'), estallar ('to explode'), ascender ('to rise') and pagar ('to pay') have in their semantic nature an internal limit and are therefore called 'perfective' or 'telic' verbs. When used in the imperfective form, these kinds of verbs

9. Examples like this are not taken into consideration: 1 de enero de 1994, según informó el propio Benegas, el número de afiliados socialistas ascendía a 350.994 personas. ('As Benegas himself reported, by January the 1 st 1994 the number of socialist members rose.IMP to 350.994 persons', CREA, El Mundo, 05/03/1994). 
(Aktionsart 'lexical aspect') seem to coerce their perfective meaning onto the imperfecto, i.e. their inherent lexical-semantic perfectivity overlaps with imperfective aspectuality. Their use in the imperfective form make the action appear dynamic thus creating the impression the action is still in progress. The use of such verbs in the imperfective form are not so typical because they are normatively required to be used in the perfective form. For example, the Corpus de la Real Academia Española (CREA) registers 96 total cases of moría (IMP) in the journalistic sections of the standard Iberian Spanish in comparison with murió (PRET) which appears in 1512 cases. The most uses of moría appear with adverbial elements that mark the temporal boundaries of the state of affairs:

(21) [...] Horas después, pasadas las dos de la madrugada, moría apuñalado por un joven.

('[...] A few hours later, after 2 o'clock in the morning, [someone] died.IMP from being stabbed by a young man', CREA, ABC Electrónico, 29/06/1997).

The use of moría in the example above (21) is modalized and behaves like an evidential marker indicating the speaker's attitude towards the source of information, which in this case, is not mentioned. The same occurs with estallaba, which is introduced by an adverbial element marking the punctual time in which the situation took place:

(22) Prosiguiendo con otros comportamientos antidemocráticos, una bomba estallaba ayer frente a la sede del partido nacionalista croatobosnio HDZ en Sarajevo.

('Continuing with some other antidemocratic behaviors, a bomb exploded.IMP yesterday in front of the headquarters of the Croatian Democratic Union of Bosnia and Herzegovina, HDZ in Sarajevo', CREA, ABC Electrónico, 14/o9/ 1997).

The following examples with ascendía and pagaba used in profits, loss, sales or purchase not only show the speakers' epistemic stance to the content of the transmitted information, ${ }^{10}$ but a pragmatic effect of speculation and doubt is produced when the information appears in imperfecto:

(23) En 1996, por ejemplo, el crédito hipotecario sumaba 85.592 millones de euros y el total ascendía a 230.030 millones [...].

('In 1996, for example, the mortgage loan reached.IMP 85.592 million euros and the total rose.IMP up to 230.030 million euros', CREA, El País, 02/01/ 2003).

10. Böhm (2013, pp. 126-127, 2016, p.366) refers also to the 'systematic use' of the Spanish imperfecto whenever it is used in stock market reports or in relation to concrete numbers, percentages and figures. 
(24) Tras abrir a 92,3, al final se pagaba a 92,87. Operadores comentaban la posibilidad de que el Banco de España hubiese intervenido, aunque con escasos resultados.

('After having opened with 92,3, at the end it was paid.IMP to 92,87. Operators talked.IMP about the possibility that the Bank of Spain should have participated, but with insufficient results', CREA, La Vanguardia, 30/03/1995).

The pragmatic effect produced by the Spanish imperfecto is also associated with the speaker's strategic communicative intention to hide the whole truth of the reality, to show his distance towards the information (cf. Díaz Salgado, 200o, p.1) or to avoid assuming responsibility on the veracity of what is said (cf. Gutiérrez Aráus, 1995b,p.179). The speaker only transmits the information without providing any information of the original author:

(25) Al cierre, el Dow Jones perdía 6 puntos, cerrando a 4.550,56 puntos.

('At the closing, the Index Dow Jones lost.IMP 6 points, closing with 4.550,56 points', CREA, La Vanguardia, 30/o6/1995).

(26) [...] el 1 de diciembre, otra bomba estallaba en un autobús y mataba a tres personas más; ese mismo mes, el día 21, 45 personas fallecían al ser activado un explosivo dentro de un automóvil en Peshawar [...].

('[...] on the 1st of December, another bomb exploded.IMP in a bus and killed.IMP three further persons; in the same month, on the 21st, 45 persons died.IMP when a bomb exploded in a car in Peshawar [...]', CREA, El Mundo, 29/04/1996).

In all the previous examples (21-26), the speakers' choice to use the imperfective form instead of the perfective one, which is grammatically required in these contexts, is then subjectively motivated to dissociate himself from his information or from the source of information, which can be unknown or uncertain. In this way, the Regresspflicht ('recourse obligation' or responsibility) for the veracity of the states of affairs is then reduced (cf. Böhm, 2013, p.125). In other words, the truthvalue of the state of affairs cannot completely be validated. The state of affairs expressed by the Spanish imperfecto is presented with open validity.

\subsection{The Spanish imperfecto with 'verbs of saying'}

The same occurs with the verbs of saying like expresar ('to express') and decir ('to say') used in the imperfective form to reproduce utterances said in a particular time, thus the speaker shows his distance from the state of affairs: 
(27) La organización terrorista expresaba de nuevo su disposición a iniciar un proceso de contactos [...].

('The terrorist organization again expressed.IMP its disposition to begin a process of contacts [...]', CREA, El Mundo, 15/o1/1996).

(28) El gran Eugene O’Neill decía que a Electra no le sentaba bien el luto. Puede decirse que a CiU los socialistas le sientan muy mal: [...] están a punto de encarcelar a su líder [...].

('The great Eugene O'Neil said.IMP that being in mourning was not Electra's thing. One can say that it does not fit $\mathrm{CiU}$, the socialists: [...] their leader is about to be imprisoned [...]', CREA, La Vanguardia, 30/05/1995).

(29) El Consejo expresaba ayer su apoyo a toda iniciativa internacional que aumente la presión sobre Milosevic y su régimen [...].

('Yesterday the council expressed.IMP its support to all international initiatives [...]', CREA, El Diario Vasco, 27/04/99).

The information has been transmitted but the author of such information is omitted. Nobody knows from whom the information comes or how information was acquired. The Spanish imperfecto can therefore refer to an external source of information, which is not mentioned by the speaker:

(30) Se decía que en cualquier momento podía llegar el lobo, y en las reuniones de ayer enseñó las orejas. Los valores [...] bancarios se vieron sometidos a una presión vendedora casi indiscriminada [...].

('It was said.IMP that the wolf could come in every moment, and in the meetings of yesterday he showed his ears. The [...] bank values were forced to submit an almost indiscriminate sale pressure [...]', CREA, El País, 02/02/1984).

By not excluding the narrative function of the Spanish imperfecto in all previous examples, the evidential use of Spanish imperfecto suits Aikhenvald's (2004, p.314) statement on the fact that "the reported evidential [...] is restricted to narratives [narrative texts] describing something that the narrator learnt from particular people, most often the narrator's ancestors".

\section{Conclusion}

On the one hand, there is a relationship between the imperfective aspectuality and the speaker's subjectivity to choose the Spanish imperfecto to express punctual and perfective situations. By using the Spanish imperfecto a situation is seen as non-concluded, undetermined or backgrounded, thus the state of affairs is presented with open validity with respect to its completion or fulfilment. It means 
one is unable to assert completely the fulfilment or veracity of the state of affairs. In this way, the imperfective aspectuality leads to the epistemic modal function of the Spanish imperfecto, by which the speaker's knowledge regarding the content of the state of affairs cannot be validated. On the other hand, it can be confirmed that the Spanish imperfecto is used as a strategy of evidentiality which developed from past tenses with secondary meanings related to the indirect information source (cf. Aikhenvald, 2004,pp.104-151). When using the Spanish imperfecto as a marker of indirect evidentiality, the speaker implicitly refers to a third source of information, which is not necessarily mentioned, and dissociates himself from it.

The imperfective aspectuality of the Spanish imperfecto (an aspectual feature at the grammatical level) in combination with perfective and telic verbs (also an aspectual feature, but at the lexical level) lead to the modal and evidential reading of the Spanish imperfecto:

- Verbs which have an intrinsic temporal endpoint like telic or perfective verbs, for example, morir ('to die') estallar ('to explode') ascender ('to rise') and pagar ('to pay'), etc., coerce their perfective meaning onto the imperfective form and distort the content of the state of affairs. A pragmatic effect of doubt, speculation or uncertainty towards the state of affairs expressed in the imperfecto is produced in the interlocutor. By the epistemic modal and evidential use of the Spanish imperfecto, these verbs are normally introduced by temporal limited adverbs, as for example hoy ('today'), ayer ('yesterday'), en [año] ('in [year]'), horas después ('few hours later'), etc.

- If the imperfecto appears with other imperfective verbs like dormía ('slept.IMP') and escribia ('wrote.IMP'), except the verbs of saying decía ('said.IMP'), expresaba ('expressed.IMP'), etc. or other imperfective verbs in which the context marks perfectivity (the endpoint and conclusion of a situation), the modal and evidential reading of the Spanish imperfecto is not possible. Let us observe this example, in which a continuous, progressive, habitual and iterative reading of the action is obtained:

(31) Lizarraga trabajaba en una empresa de Pamplona, de donde se despidió con una calificación de "inutilidad total" [...].

('Lizarraga worked.IMP (used to work) in a company of Pamplona, from where he left with the qualification of "total incapacity" [...], CREA, El País, 02/ 02/1984).

Therefore, the contextual information confirms the use of the Spanish imperfecto as being epistemic modal and evidential. According to the narrator's perspective to choose a specific tense to tell a story, the narrative Spanish imperfecto is related to the indirect evidentiality to mark implicitly that the narrator of the story is not the author of such information. 


\section{References}

Aikhenvald, A. (2004). Evidentiality. Oxford: University Press.

Bazzanella, C. (1990). Modal uses of the Italian Indicativo Imperfetto in a pragmatic perspective. Journal of Pragmatics, 14, 439-457.

https://doi.org/10.1016/0378-2166(90)90100-R

Bertinetto, P. M. (1986). Tiempo, aspetto e azione nel verbo italiano: Il sistema dell'indicativo. Florenz: Presso L'Academia della Crusca.

Böhm, V. (2013). Evidentielle Markierung von fremden Äußerungen. Eine Analyse des spanischen Imperfekts in journalistischen Texten. In A. Hennemann, \& C. Schlaak (Eds.), Korpuslinguistische Untersuchungen. Analysen einzelsprachlicher Phänomene (pp. 119-130). Berlin: Frank \& Timme GmbH.

Böhm, V. (2016). La imperfectividad en la prensa española y su relación con las categorías semánticas de modalidad y evidencialidad. Peter Lang: Frankfurt am Main. https://doi.org/10.3726/978-3-653-06436-0

Böhm, V., \& Hennemann, A. (2014). The evidential use of the Spanish imperfect and the conditional in journalistic contexts. Studia Neophilologica, 86, 1-18. https://doi.org/10.1080/00393274.2014.933661

Böhm, V., \& Hennemann, A. (in press). La codificación de la evidencialidad en el quechua y guaraní: Su transferencia en algunas variedades del español americano y su interconexión con la temporalidad, aspectualidad y modalidad. In V. Böhm, \& A. Hennemann (Eds.), La interconexión y el solapamiento de la temporalidad, aspectualidad, modalidad y evidencialidad en las diversas variedades del español. Frankfurt am Main: Peter Lang.

Bres, J. (2005). L'imparfait dit narratif. CNRS Èditions: Paris.

Bybee, J., \& Fleischmann, S. (1995). Modality in grammar and discourse. An introductory essay. In J. Bybee, \& S. Fleischmann (Eds.), Modality in grammar and discourse (pp. 1-14). Amsterdam/Philadelphia: John Benjamins Publishing Company. https://doi.org/10.1075/tsl.32

Cappon, R. J. (2005). Journalistisches Schreiben. Berlin: Autorenhaus Verlag.

Dessì, S. (2010). Modal uses of the Italian imperfetto and the Spanish imperfecto: A comparison. In M.G. Becker, \& E.-M. Remberger (Eds.), Modality and mood in Romance. Modal interpretation, mood selection, and mood alternation (pp. 39-66). Berlin: Walter de Gruyter.

Díaz Salgado, L.C. (2000). La decoración del drama. Venezuela Analítica, Núm. Nov. 200o, 1-1.

Fernández Ramírez, S. (1986). Gramática Española. El verbo y la oración. Madrid: Arco/Libros.

García Fernández, L. (2004). El pretérito imperfecto: repaso histórico y bibliográfico. In L. García Fernández, \& B. Camus Bergareche (Eds.), El pretérito imperfecto (pp. 13-95). Madrid: Gredos.

Giacalone Ramat, A., \& Topadze, M. (2007). The coding of evidentiality: A comparative look at Georgian and Italian. Italian Journal of Linguistics 19(1), 7-38.

Gutiérrez Aráus, M.L. (1995a). Formas temporales del pasado en indicativo. Madrid: Arcos Libros.

Gutiérrez Aráus, M.L. (1995b). Sobre los valores secundarios del imperfecto. ASELE, Actas VI, 177-185. 
Haßler, G. (2012). Indicative verb forms as means of expressing modality in Romance languages. In W. Abraham, \& E. Leiss (Eds.), Covert patterns of modality (pp. 133-152). Cambridge: Cambridge Scholars.

Laprade, R.A. (1981). Some cases of Aymara influence on La Paz Spanish. In M. Hardman (Ed.), The Aymara language in its social and cultural context: A collection of essays on aspects of Aymara language and culture (pp. 207-227). Gainesville: University Presses of Florida.

Leonetti, M., \& Escandell-Vidal, V. (2003). On the quotative readings of Spanish imperfecto. Cuadernos de Lingüística, $X, 135-154$.

Nuyts, J. (2001). Epistemic modality, language, and conceptualization. A cognitive-pragmatic perspective. Amsterdam/Philadelphia: John Benjamins Publishing Company. https://doi.org/10.1075/hcp.5

Real Academia Española (2009). NGLE: Nueva gramática de la lengua española. Madrid: Espasa Libros.

Real Academia Española (2010). Nueva gramática de la lengua española. Manual. Madrid: Espasa Libros.

Real Academia Española. Corpus de referencia del español actual. CREA, Banco de datos [en línea] de la Real Academia Española, retrieved on 29.05.2019, from http://www.rae.es/

Reyes, G. (1990a). Tiempo, modo, aspecto e intertextualidad. Revista Española Lingüística, 20, 17-53.

Reyes, G. (199ob). Valores estilísticos del imperfecto. Revista de Filología Española, Vol. LXX, $\mathrm{N}^{\circ} 1 / 2,46-70$.

Reyes, G. (1996). Los procedimientos de cita: Citas encubiertas y ecos. Madrid: Arco Libros.

Volkmann, G. (2005). Weltsicht und Sprache. Epistemische Relativierung am Beispiel des Spanischen. Tübingen: Gunter Narr.

Wachtmeister, F. (2005). Evidencialidad. La codificación lingüística del punto de vista. Tesis doctoral, Stockholms Universitet.

Watkins, L. (1984). A grammar of Kiowa. Lincoln and London: University of Nebraska Press.

\title{
Address for correspondence
}

\author{
Verónica Böhm \\ Universität Potsdam \\ Institut für Romanistik, (Romance Languages) \\ Am Neuen Palais 10 \\ 14469 Potsdam \\ Germany \\ veronica.boehm@uni-potsdam.de
}

